\title{
Synthesis and cholinesterase inhibitory activity of some phenylacetamide derivatives bearing $1 \mathrm{H}$-pyrazole or $1 \mathrm{H}$-1,2,4-triazole
}

\author{
Ayşe H. TARİKOĞULLARI, M. Murat ÇİZMECİOĞLU, Merve SAYLAM, Sülünay PARLAR, Vildan ALPTÜZÜN, \\ Zeynep SOYER
}

\begin{abstract}
A group of $\mathrm{N}$-phenylacetamide derivatives bearing five membered heterocyclic rings, pyrazole or 1,2,4-triazole, were synthesized to investigate their cholinesterase inhibitory activities. Acetylcholinesterase (AChE) and butyrylcholinesterase (BuChE) inhibitory activities were evaluated by using Ellman's spectroscopic method. Results
\end{abstract}

indicated that all of the compounds displayed moderate and selective AChE inhibitory activity and the most active compound was 2-(1H-1,2,4-triazole-1-yl)- $N$-(3-methoxyphenyl)acetamide with an $\mathrm{IC}_{50}$ value of $6.68 \mu \mathrm{M}$. Docking studies were also carried out for the most active compound.

Keywords: Alzheimer's disease, pyrazole, 1,2,4-triazole, acetamide, cholinesterase inhibitory activity
Ayşe H. Tarikoğulları, M. Murat Çizmecioğlu, Merve Saylam, Sülünay Parlar, Vildan Alptüzün, Zeynep Soyer Department of Pharmaceutical Chemistry, Faculty of Pharmacy, Ege University, Bornova, Izmir 35100, Turkey

Corresponding author:

Ayşe H. Tarikoğulları

Department of Pharmaceutical Chemistry

Faculty of Pharmacy, Ege University, Bornova, Izmir 35100, Turkey

Phone: +90 5323173412

Telefax: +902323885258

E-mail: ayse.tarikogullari@ege.edu.tr

\section{INTRODUCTION}

Alzheimer's disease (AD) is the most common cause of dementia in the elderly. It is characterized by irreversible degeneration of the cholinergic neurons in the brain, accompanied with progressive loss of memory and cognitive skills $(1,2)$. As much of the functional deficit in $\mathrm{AD}$ has been associated with morphological and functional imbalance of the central cholinergic system, choline levels play an important role in the treatment of $\mathrm{AD}$ (3). According to the cholinergic hypothesis, the cognitive and memory symptoms of $\mathrm{AD}$ are caused by the diminution of acetylcholine, therefore the most common strategy is to increase acetylcholine (ACh) level by inhibiting acetylcholinesterase (AChE) enzyme (4). Currently, the therapeutic approach reflecting this hypothesis is the treatment with FDA approved drugs like donepezil, rivastigmine and galanthamine as AChE inhibitors (1).

Heterocyclic compounds are potentially important nuclei for drug discovery as they can interact with molecular targets with various binding interaction possibilities. Donepezil, rivastigmine and galanthamine also carry heterocyclic rings and according to literature survey, most of the compounds that have exhibited AChE inhibition consists of heterocyclic ring systems including pyrazole and 1,2,4-triazole (5-14). Besides AChE inhibitory activity, pyrazole and 1,2,4-triazole containing systems have a wide 
spectrum of biological activities such as antibacterial, antifungal, analgesic, antipyretic, antiinflammatory, antiviral, anticancer, antituberculosis, antiparasitic, antihyperglycemic, antidepression, antihypertensive, vasodilatory, anticonvulsant activity $(5,9,10,14-16)$.

AChE enzyme structure is a deep and narrow gorge approximately $20 \AA$ long consisting of 2 binding sites, peripheral anionic site (PAS) and catalytic active site (CAS). The PAS is the entrance of the enzyme gorge whereas the CAS is the bottom of the gorge (17). The PAS of the AChE gorge (for AChE in Torpedo californica - TcAChE) includes Tyr70, Asp72, Tyr121, Glu278, Trp279 and Tyr334 residues that are important for binding interactions of the inhibitors. In the middle of the TcAChE gorge, Trp84, Tyr130, Glu199, Phe330 and Tyr442 are also five important amino acid residues constituting the anionic binding site (18). Molecular modeling studies indicated that AChE inhibitors bearing heterocyclic rings interact with specific amino acids of either/ both CAS and PAS site of AChE $(18,19)$. Besides, the narrow conformation of the enzyme gorge leads small molecules like tacrine and donepezil to fit into the active site easily (1).

In the light of these findings, we designed a group of $\mathrm{N}$-phenylacetamide derivatives bearing pyrazole and 1,2,4-triazole to test their cholinesterase inhibitory activity. We also evaluated the contribution of the substituents on $\mathrm{N}$-phenyl ring to AChE inhibitory activity.

\section{MATERIALS AND METHODS}

\section{Chemistry}

Analytical thin-layer chromatography (TLC) was run on Merck silica gel plates (Kieselgel 60F254) with detection by UV light $(254 \mathrm{~nm})$. Melting points were determined on Stuart SMP30 melting point apparatus and are uncorrected. The IR spectra of compounds were recorded as potassium bromide pellets on Perkin Elmer FT-IR Spectrometer 100 (Perkin Elmer Inc., Massachusetts, USA). The NMR spectra of compounds were recorded on a Varian As 400 Mercury Plus NMR (Varian Inc., Palo Alto, CA, USA) spectrometer. HRMS was recorded on a HPLC-TOF Waters Micromass LCT Premier XE (Milford, MA, USA) mass spectrometer using ESI. All starting materials and reagents were highgrade commercial products.

The title compounds were synthesized in two steps. First, substituted anilines and 2-chloroacetyl chloride were reacted to obtain 2-chloroanilides according to the reported procedure (20), then they were condensed with pyrazole or 1,2,4-triazole to furnish the title compounds (Scheme 1).

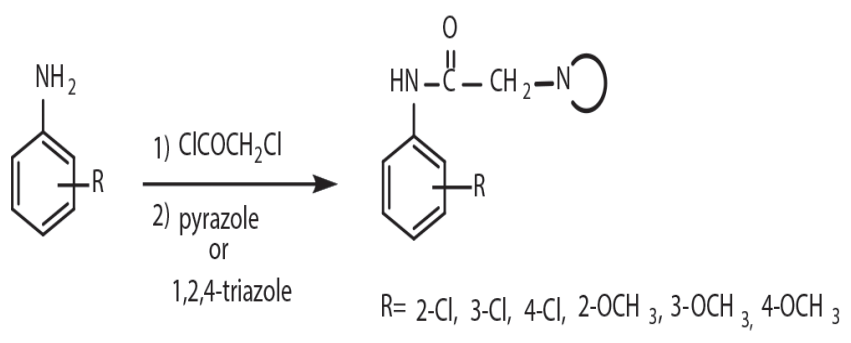

Scheme 1. The synthetic pathway of the title compounds

\section{General procedure for the synthesis of the intermediates}

Substituted anilines ( $0.066 \mathrm{~mol}, 1.0$ equiv.) were dissolved in glacial acetic acid $(25 \mathrm{~mL}) .2$-chloroacetyl chloride $(0.074$, 1.12 equiv.) was added by a seperatory funnel drop wise in an ice bath. After the reaction mixture was stirred for 15 minutes in ice bath then at room temperature for 45 minutes, the reaction mixture was poured into saturated sodium acetate solution and the precipitate was filtered and washed with water. The crude product was dried and crystallized from ethanol:water mixture (20).

\section{General procedure for the synthesis of the compounds 1-12}

2-chloro- $\mathrm{N}$-phenylacetamides (1.0 equiv.) and pyrazole or 1,2,4-triazole (5.0 equiv.) were refluxed in toluene $(8-10 \mathrm{~mL})$. After confirming the end of the reaction by TLC, the solvent was evaporated. The residue was dissolved in chloroform $(30 \mathrm{~mL})$ and extracted with water $(2 \times 10 \mathrm{~mL})$. The organic phases were combined and dried over anhydrous $\mathrm{Na}_{2} \mathrm{SO}_{4}$ and evaporated under reduced pressure. The product was purified by crystallization from water (15). The synthetic pathway is given in Scheme 1.

$\mathrm{N}$-(2-chlorophenyl)-2-(1H-pyrazol-1-yl)acetamide (1)

Yield $67 \%$; mp: $105^{\circ} \mathrm{C}$ (water) (lit ${ }^{21}$ : mp: $110{ }^{\circ} \mathrm{C}$ ); IR (KBr) ${ }_{\max }\left(\mathrm{cm}^{-1}\right): 3267$ (NH st), 1677 (amide I), 1546 (amide II); ${ }^{1} \mathrm{H}$ NMR (DMSO-d $) 8.69$ (brs, NH), 8.34 (dd, $J: 1.5,8.2$ $H z, 1 \mathrm{H}, \mathrm{PhH}), 7.74$ (d, J: $2.0 \mathrm{~Hz}, 1 \mathrm{H}, \mathrm{PyH}), 7.55$ (d, J: 2.4 $H z, 1 \mathrm{H}, \mathrm{PyH}), 7.31$ (dd, J: 1.3, 7.9 Hz, 1H, PhH), 7.24 (m, $1 \mathrm{H}, \mathrm{PhH}), 7.03(\mathrm{td}, J: 1.5,7.6 \mathrm{~Hz}, 1 \mathrm{H}, \mathrm{PhH}), 6.41(\mathrm{t}, J: 2.2$ $\mathrm{Hz}, 1 \mathrm{H}, \mathrm{PyH}), 4.99$ (s, 2H, $\left.\mathrm{CH}_{2}\right)$ ppm.; HR-MS $\left(\mathrm{EI}^{+}\right), \mathrm{m} / \mathrm{z}$ : $236.0600\left(\mathrm{M}^{+}, \mathrm{C}_{11} \mathrm{H}_{11} \mathrm{~N}_{3} \mathrm{OCl}\right.$ for 236.0591).

$\mathrm{N}$-(3-chlorophenyl)-2-(1H-pyrazol-1-yl)acetamide (2)

Yield $88 \%$; mp: $80{ }^{\circ} \mathrm{C}$ (water) (lit $\left.{ }^{21}: \mathrm{mp}: 62^{\circ} \mathrm{C}\right)$; IR (KBr) ${ }_{\max }\left(\mathrm{cm}^{-1}\right): 3325$ (NH st), 1676 (amide I), 1549 (amide II); ${ }^{1} \mathrm{H}$ $\operatorname{NMR}\left(\mathrm{CDCl}_{3}\right) 8.64$ (brs, NH), 7.71 (d, J: $1.6 \mathrm{~Hz}, 1 \mathrm{H}, \mathrm{PyH}$ ), 7.56 (t, J: $2.0 \mathrm{~Hz}, 1 \mathrm{H}, \mathrm{PhH}$ ), 7.53 (d, J: $2.3 \mathrm{~Hz}, 1 \mathrm{H}, \mathrm{PyH}$ ), $7.30(\mathrm{~m}, 1 \mathrm{H}, \mathrm{PhH}), 7.21$ (t, J: $7.5 \mathrm{~Hz}, 1 \mathrm{H}, \mathrm{PhH}), 7.07$ (m, 1H, $\mathrm{PhH}), 6.39$ (t, J: $2.2 \mathrm{~Hz}, 1 \mathrm{H}, \mathrm{PyH}), 4.93\left(\mathrm{~s}, 2 \mathrm{H}, \mathrm{CH}_{2}\right)$ 
ppm.; HR-MS (EI'), m/z: $236.0597\left(\mathrm{M}^{+}, \mathrm{C}_{11} \mathrm{H}_{11} \mathrm{~N}_{3} \mathrm{OCl}\right.$ for 236.0591).

N-(4-chlorophenyl)-2-(1H-pyrazol-1-yl)acetamide (3)

Yield $70 \%$; mp: $175^{\circ} \mathrm{C}$ (water); IR (KBr) ${ }_{\text {max }}\left(\mathrm{cm}^{-1}\right): 3274$ (NH st), 1698 (amide I), 1551 (amide II); ${ }^{1} \mathrm{H}$ NMR ( $\mathrm{CDCl}_{3}$ ) 8.58 (brs, NH), 7.71 (d, J: $1.9 \mathrm{~Hz}, 1 \mathrm{H}, \mathrm{PyH}), 7.53$ (d, J: 2.3 $\mathrm{Hz}, 1 \mathrm{H}, \mathrm{PyH}), 7.40$ (dd, J: 2.2, $6.9 \mathrm{~Hz}, 2 \mathrm{H}, \mathrm{Ph} 2 \mathrm{H}), 7.25$ (m, 2H, Ph2H), 6.39 (t, J: $2.2 \mathrm{~Hz}, 1 \mathrm{H}, \mathrm{PyH}), 4.93$ (s, 2H, $\mathrm{CH}_{2}$ ) ppm.; HR-MS (EI+), m/z: $236.0598\left(\mathrm{M}^{+}, \mathrm{C}_{11} \mathrm{H}_{11} \mathrm{~N}_{3} \mathrm{OCl}\right.$ for 236.0591).

\section{N-(2-methoxyphenyl)-2-(1H-pyrazol-1-yl)acetamide (4)}

Yield $57 \%$; mp: $64{ }^{\circ} \mathrm{C}$ (water); IR (KBr) ${ }_{\text {max }}\left(\mathrm{cm}^{-1}\right): 3270$ (NH-st), 1668 (amide I), 1542 (amide II); ${ }^{1} \mathrm{H} \mathrm{NMR}\left(\mathrm{CDCl}_{3}\right.$ ) 8.54 (brs, NH), 8.30 (dd, J: 1.6, $8.0 \mathrm{~Hz}, 1 \mathrm{H}, \mathrm{PhH}), 7.71$ (d, $J: 1.8 \mathrm{~Hz}, 1 \mathrm{H}, \mathrm{PyH}), 7.54$ (d, J: $2.3 \mathrm{~Hz}, 1 \mathrm{H}, \mathrm{PyH}), 7.02$ (td, $J: 1.6,7.8 \mathrm{~Hz}, 1 \mathrm{H}, \mathrm{PhH}), 6.94$ (td, J: 1.2, $7.5 \mathrm{~Hz}, 1 \mathrm{H}, \mathrm{PhH})$, 6.82 (dd, J: 1.2, $8.1 \mathrm{~Hz}, 1 \mathrm{H}, \mathrm{PhH}), 6.40$ (t, J: $2.2 \mathrm{~Hz}, 1 \mathrm{H}$, $\mathrm{PyH}), 4.97$ (s, 2H, $\left.\mathrm{CH}_{2}\right), 3.78$ (s, 3H, $\left.\mathrm{OCH}_{3}\right)$ ppm.; HR-MS $\left(\mathrm{EI}^{+}\right), \mathrm{m} / \mathrm{z}: 232.1087\left(\mathrm{M}^{+}, \mathrm{C}_{12} \mathrm{H}_{14} \mathrm{~N}_{3} \mathrm{O}_{2}\right.$ for 232.1086).

$\mathrm{N}$-(3-methoxyphenyl)-2-(1H-pyrazol-1-yl)acetamide (5)

Yield $65 \%$; mp: $70{ }^{\circ} \mathrm{C}$ (water); IR (KBr) ${ }_{\text {max }}\left(\mathrm{cm}^{-1}\right): 3271$ (NH-st), 1691 (amide I), 1562 (amide II), ${ }^{1} \mathrm{H}$ NMR $\left(\mathrm{CDCl}_{3}\right)$ 8.20 (brs, NH), 7.70 (d, J: $2.0 \mathrm{~Hz}, 1 \mathrm{H}, \mathrm{PyH}), 7.53$ (d, J: $2.4 \mathrm{~Hz}, 1 \mathrm{H}, \mathrm{PyH}), 7.17$ (m, 2H, Ph2H), 6.90 (dd, J: 1.8, 8.1 $\mathrm{Hz}, 1 \mathrm{H}, \mathrm{PhH}), 6.66$ (dd, J: 2.4, $8.2 \mathrm{~Hz}, 1 \mathrm{H}, \mathrm{PhH}), 6.38$ (t, J: $2.0 \mathrm{~Hz}, 1 \mathrm{H}, \mathrm{PyH}), 4.93\left(\mathrm{~s}, 2 \mathrm{H}, \mathrm{CH}_{2}\right), 3.78\left(\mathrm{~s}, 3 \mathrm{H}, \mathrm{OCH}_{3}\right)$ ppm.; HR-MS $\left(\mathrm{EI}^{+}\right), \mathrm{m} / \mathrm{z}: 232.1089\left(\mathrm{M}^{+}, \mathrm{C}_{12} \mathrm{H}_{14} \mathrm{~N}_{3} \mathrm{O}_{2}\right.$ for 232.1086);

\section{N-(4-methoxyphenyl)-2-(1H-pyrazol-1-yl)acetamide (6)}

Yield 60 \%; mp: $133{ }^{\circ} \mathrm{C}$ (water); IR (KBr) ${ }_{\text {max }}\left(\mathrm{cm}^{-1}\right)$ : 3324 (NH-st), 1682 (amide I), 1555 (amide II); ${ }^{1} \mathrm{H}$ NMR $\left(\mathrm{CDCl}_{3}\right.$ ) 8.12 (brs, NH), 7.69 (d, J: $2.0 \mathrm{~Hz}, 1 \mathrm{H}, \mathrm{PyH}$ ), 7.53 (d, J: 2.3 $\mathrm{Hz}, 1 \mathrm{H}, \mathrm{PyH}$ ), 7.34 (dd, J: 2.2, $7.0 \mathrm{~Hz}, 2 \mathrm{H}, \mathrm{Ph} 2 \mathrm{H}$ ), 6.83 (dd, J: 2.2, 7.0 Hz, 2H, Ph2H), 6.38 (t, J: $2.2 \mathrm{~Hz}, 1 \mathrm{H}, \mathrm{PyH}), 4.93$ (s, 2H, $\left.\mathrm{CH}_{2}\right), 3.77$ (s, 3H, $\left.\mathrm{OCH}_{3}\right)$ ppm.; HR-MS (EI'), m/z: 232.1081 ( $\mathrm{M}^{+}, \mathrm{C}_{12} \mathrm{H}_{14} \mathrm{~N}_{3} \mathrm{O}_{2}$ for 232.1086).

$\mathrm{N}$-(2-chlorophenyl)-2-(1H-1,2,4-triazol-1-yl)acetamide (7)

Yield $27 \%$; mp: $131{ }^{\circ} \mathrm{C}$ (water); IR (KBr) ${ }_{\max }\left(\mathrm{cm}^{-1}\right)$ : 3255 (NH-st), 1674 (amide I), 1552(amide II); ${ }^{1} \mathrm{H}$ NMR (DMSO-d D 9.93 (brs, NH), 8.53 (s, 1H, TrH), 7.98 (s, 1H, TrH), 7.72 (d, J: $8.2 \mathrm{~Hz}, 1 \mathrm{H}, \mathrm{PhH}), 7.50$ (d, J: $8.2 \mathrm{~Hz}, 1 \mathrm{H}$, $\mathrm{PhH}), 7.32$ (t, J: $7.7 \mathrm{~Hz}, 1 \mathrm{H}, \mathrm{PhH}), 7.20$ (t, J: $7.9 \mathrm{~Hz}, 1 \mathrm{H}$, $\mathrm{PhH}), 5.23$ (s, 2H, $\mathrm{CH}_{2}$ ) ppm.; HR-MS (EI $\left.{ }^{+}\right), \mathrm{m} / \mathrm{z}: 237.0542$ $\left(\mathrm{M}^{+}, \mathrm{C}_{10} \mathrm{H}_{10} \mathrm{~N}_{4} \mathrm{OCl}\right.$ for 237.0543).

N-(3-chlorophenyl)-2-(1H-1,2,4-triazol-1-yl)acetamide (8)

Yield $35 \%$; mp: $157{ }^{\circ} \mathrm{C}$ (water); IR (KBr) ${ }_{\max }\left(\mathrm{cm}^{-1}\right)$ :
3260 (NH-st), 1705 (amide I), 1550 (amide II); ${ }^{1} \mathrm{H}$ NMR $\left(\mathrm{DMSO}_{6}\right.$ ) 10.56 (brs, NH), 8.53 (s, 1H, TrH), 7.97 (s, 1H, TrH), 7.74 (t, J: $2.2 \mathrm{~Hz}, 1 \mathrm{H}, \mathrm{PhH}), 7.42$ (m, 1H, PhH), 7.34 (t, J: $8.2 \mathrm{~Hz}, 1 \mathrm{H}, \mathrm{PhH}), 7.12$ (m, J: $7.4 \mathrm{~Hz}, 1 \mathrm{H}, \mathrm{PhH}$ ), 5.13 (s, 2H, $\left.\mathrm{CH}_{2}\right)$ ppm.; HR-MS $\left(\mathrm{EI}^{+}\right), \mathrm{m} / \mathrm{z}: 237.0547\left(\mathrm{M}^{+}\right.$, $\mathrm{C}_{10} \mathrm{H}_{10} \mathrm{~N}_{4} \mathrm{OCl}$ for 237.0543).

N-(4-chlorophenyl)-2-(1H-1,2,4-triazol-1-yl)acetamide (9)

Yield $30 \%$; mp: $205{ }^{\circ} \mathrm{C}$ (water); IR (KBr) ${ }_{\max }\left(\mathrm{cm}^{-1}\right)$ : 3264 (NH-st), 1704 (amide I), 1557 (amide II); ${ }^{1} \mathrm{H}$ NMR (DMSO-d ) 10.48 (brs, NH), 8.45 (s, 2H, Tr2H), 7.58 (d, J: $9.0 \mathrm{~Hz}, 2 \mathrm{H}, \mathrm{Ph}-\mathrm{H}), 7.36$ (d, J: $8.6 \mathrm{~Hz}, 2 \mathrm{H}, \mathrm{PhH}), 5.00$ (s, 2H, $\left.\mathrm{CH}_{2}\right)$ ppm.; HR-MS (EI $\left.{ }^{+}\right), \mathrm{m} / \mathrm{z}: 237.0548\left(\mathrm{M}^{+}, \mathrm{C}_{10} \mathrm{H}_{10} \mathrm{~N}_{4} \mathrm{OCl}\right.$ for 237.0543).

N-(2-methoxyphenyl)-2-(1H-1,2,4-triazol-1-yl)acetamide (10)

Yield $17 \%$; mp: $176{ }^{\circ} \mathrm{C}$ (water); IR (KBr) ${ }_{\max }\left(\mathrm{cm}^{-1}\right)$ : 3269 (NH-st), 1708 (amide I), 1556 (amide II); ${ }^{1} \mathrm{H}$ NMR (DMSO-d $)_{6} 10.37$ (brs, NH), 8.54 (s, 1H, TrH), 7.99 (s, $1 \mathrm{H}, \mathrm{TrH}), 7.26$ (s, 1H, PhH), 7.21 (t, J: $8.1 \mathrm{~Hz}, 1 \mathrm{H}, \mathrm{PhH})$, 7.08 (d, J: $7.6 \mathrm{~Hz}, 1 \mathrm{H}, \mathrm{PhH}), 6.67$ (dd, J: 2.2, 8.1 Hz, 1H, $\mathrm{PhH}), 5.12$ (s, 2H, $\left.\mathrm{CH}_{2}\right), 4.01$ (s, 3H, $\left.\mathrm{OCH}_{3}\right)$ ppm.; HR-MS $\left(\mathrm{EI}^{+}\right), \mathrm{m} / \mathrm{z}: 233.1046\left(\mathrm{M}^{+}, \mathrm{C}_{11} \mathrm{H}_{13} \mathrm{~N}_{4} \mathrm{O}_{2}\right.$ for 233.1039).

$N$-(3-methoxyphenyl)-2-(1H-1,2,4-triazol-1-yl)acetamide (11)

Yield $56 \%$; mp: $176{ }^{\circ} \mathrm{C}$ (water); IR (KBr) ${ }_{\max }\left(\mathrm{cm}^{-1}\right)$ : 3269 (NH-st), 1707 (amide I), 1557 (amide II); ${ }^{1} \mathrm{H}$ NMR (DMSO-d D 10.34 (brs, NH), 8.52 (s, 1H, TrH), 7.97 (s, 1H, TrH), 7.25 (s, 1H, PhH), 7.21 (t, J: $8.1 \mathrm{~Hz}, 1 \mathrm{H}, \mathrm{PhH}$ ), 7.08 (d, J: $8.0 \mathrm{~Hz}, 1 \mathrm{H}, \mathrm{PhH}), 6.65$ (d, J: $8.2 \mathrm{~Hz}, 1 \mathrm{H}, \mathrm{PhH}$ ), $5.1\left(\mathrm{~s}, 2 \mathrm{H}, \mathrm{CH}_{2}\right), 3.70$ (s, 3H, $\left.\mathrm{OCH}_{3}\right)$ ppm.; HR-MS $\left(\mathrm{EI}^{+}\right)$, $\mathrm{m} / \mathrm{z}: 233.1041\left(\mathrm{M}^{+}, \mathrm{C}_{11} \mathrm{H}_{13} \mathrm{~N}_{4} \mathrm{O}_{2}\right.$ for 233.1039).

$N$-(4-methoxyphenyl)-2-(1H-1,2,4-triazol-1-yl)acetamide (12)

Yield $33.4 \%$; mp: $167^{\circ} \mathrm{C}$ (water); IR (KBr) ${ }_{\max }\left(\mathrm{cm}^{-1}\right)$ : 3269 (NH-st), 1683 (amide I), 1565 (amide II); ${ }^{1} \mathrm{H}$ NMR (DMSO-d D $_{6} 10.21$ (brs, NH), 8.51 (s, 1H, TrH), 7.96 (d, J: $1.6 \mathrm{~Hz}, 1 \mathrm{H}, \mathrm{TrH}), 7.47$ (d, J: $7.1 \mathrm{~Hz}, 2 \mathrm{H}, \mathrm{Ph} 2 \mathrm{H}), 6.88$ (d, J: $7.1 \mathrm{~Hz}, 2 \mathrm{H}, \mathrm{Ph} 2 \mathrm{H}), 5.07$ (s, 2H, $\left.\mathrm{CH}_{2}\right), 3.70$ (d, J: 1.8 $\left.\mathrm{Hz}, 3 \mathrm{H}, \mathrm{OCH}_{3}\right)$ ppm.; HR-MS $\left(\mathrm{EI}^{+}\right), \mathrm{m} / \mathrm{z}: 233.1044\left(\mathrm{M}^{+}\right.$, $\mathrm{C}_{11} \mathrm{H}_{13} \mathrm{~N}_{4} \mathrm{O}_{2}$ for 233.1039).

\section{Biological activity}

Acetylcholinesterase E.C.3.1.1.7., (Type VI-S, from electric eel) and butyrylcholinesterase E.C. 3.1.1.8, from equine serum were purchased from Sigma-Aldrich (Steinheim, Germany). 5,5'-Dithiobis(2-nitrobenzoic acid) 
(DTNB)-Ellman's reagent, buffer compounds (potassium dihydrogen phosphate, potassium hydroxide), sodium hydrogen carbonate, acetylthiocholine iodide (ATC) and butyrylthiocholine iodide (BTC) were obtained from Fluka (Buchs, Switzerland). Spectrophotometric measurements were performed on a Shimadzu UV/160-A Spectrophotometer.

\section{Acetylcholinesterase/butyrylcholinesterase activity assay}

Enzyme activity was investigated using a slightly modified colorimetric method of Ellman et al. $(22,23)$. Thiocholine, the product of the enzymatic hydrolysis, does not possess a significant chromophore in UV detection, therefore DTNB (Ellman's reagent) was used as a chromogenic reagent for the evaluation of enzyme activity.

Stock solutions of the inhibitor compounds were prepared in 2\% DMSO, which were diluted with aqueous assay medium to a final content of organic solvent always lower than $0.2 \%$. The enzyme activity was determined in the presence of at least five different concentrations of an inhibitor, generally between $10^{-3}$ and $10^{-8}$, in order to obtain the inhibition of AChE or BuChE activity between $0 \%$ and $100 \%$. Each concentration was assayed in triplicate. Prior to use, all solutions were adjusted to $20^{\circ} \mathrm{C}$. Enzyme solution (2.5 units/ $\mathrm{mL}, 100 \mu \mathrm{L})$ and inhibitor solution $(100 \mu \mathrm{L})$ were added into a cuvette containing the phosphate buffer $(3.0 \mathrm{~mL}, 0.1 \mathrm{M} ; \mathrm{pH}$ = 8.0). After $5 \mathrm{~min}$ of incubation, DTNB solution $(0.01 \mathrm{M}$, $100 \mu \mathrm{L})$ and ATC/BTC iodide $(0.075 \mathrm{M}, 20 \mu \mathrm{L})$ were added. After a rapid and immediate mixing, the absorption was measured at $412 \mathrm{~nm}$ (23).

\section{Molecular Docking Study}

The crystal structure of Donepezil in complex with AChE were taken from the Protein Data Bank (pdb codes: 1EVE resolved at $2.5 \AA$ ). Heteroatoms and water molecules in the PDB file were removed and hydrogen atoms were added to the protein by using MOE 2014.09.1 (24). Prior to the docking calculations, an energy minimization using the AMBER99 force field was performed on the enzyme. Compound 11 were built and protonated using the protonate 3D protocol and energy minimized using the MMFF94 force field in MOE 2014.09.1. Docking of the ligand was carried out using the GOLD 5.2.1 program with default settings (25). A sphere of $20 \AA$ around the carbonyl group of Glu199 was defined as the binding site for the ligand docking and 100 confirmations was allowed. The Goldscore standard precision (sp) were calculated and analyzed.

\section{RESULTS AND DISCUSSION}

\section{Chemistry}

In this study, twelve 2-(1H-1,2,4-triazole-1yl)- $N$ (substitutedphenyl)acetamide and 2-(1H-pyrazole-1yl)- $N$ (substitutedphenyl)acetamide derivatives were synthesized to evaluate their cholinesterase inhibitory activity. For this purpose, appropriate anilines were reacted with 2-chloroacetyl chloride to obtain the intermediates. Then they refluxed with pyrazole or 1,2,4-triazole to reach the final compounds. The structures of the title compounds were confirmed by IR, ${ }^{1} \mathrm{H}-\mathrm{NMR}$ and HR-MS spectral analysis.

Among the synthesized compounds, compounds 3, 4, 5, 6, 7 and $\mathbf{1 1}$ are listed in the literature with registry numbers CASRN 1171420-10-2, 1324900-89-1, 1324432-08-7, 942863-57-2, 1457699-94-3, 1222962-44-8 respectively, but corresponding scientific reference data are not available. Compounds 1 (21), 2 (21), 8 (26), 9 (27), 10 (26) and 12 (26) were reported previously.

In the IR spectra, carbonyl stretching band was recorded between 1708-1668 $\mathrm{cm}^{-1}$ and $\mathrm{N}-\mathrm{H}$ stretching band was observed between 3324-3255 $\mathrm{cm}^{-1}$ supporting the presence of the amide structure for the title compounds $(28,29)$.

The NMR data of the title compounds were recorded in $\mathrm{CDCl}_{3}$ or DMSO- $\mathrm{d}_{6}$ solution and are in complete agreement with the expected resonance signals in terms of chemical shifts and integrations (28). In the aliphatic region, the methylene protons were observed between $\delta$ 4.99-4.93 for pyrazole derivatives and $\delta$ 5.23-5.07 for 1,2,4-triazole derivatives. Thus, the proton signals of the methoxy substituents on phenyl ring were observed as expected between $\delta$ 4.01-3.70. In the aromatic region, the proton signals of $\mathrm{N}$-phenyl ring were recorded at expected chemical shifts with supporting splitting patterns. Also, the protons of the 5 membered rings were recorded with relevant splitting patterns and integration values. N-H protons were observed between $\delta$ 8.69-8.12 for pyrazole derivatives and $\delta$ 10.56-9.93 for 1,2,4-triazole derivatives depending on the structure of the compound.

The structure and the purity of the title compounds was further verified by HR-MS. The molecular ions of the compounds are in complete agreement with the calculated molecular weights and the purities are in the expected range.

\section{Cholinesterase Inhibitory Activity}

Inhibitory potency of the final compounds against cholinesterase enzymes were evaluated by the spectroscopic method as described in the literature (22). The $\mathrm{AChE} / \mathrm{BuChE}$ inhibitory activity results are summarized as $\mathrm{IC}_{50}$ values in Table 1. 
Table 1. In vitro cholinesterase activity of the title compounds

\begin{tabular}{ccc}
\hline Compound & $\mathrm{AChE} \mathrm{IC}_{50} \pm \mathrm{SEM}(\mu \mathrm{M})^{\mathrm{a}}$ & $\mathrm{BuChE} \mathrm{IC}_{50} \pm \mathrm{SEM}(\mu \mathrm{M})^{\mathrm{a}}$ \\
\hline 1 & $11.40 \pm 0.61$ & $>100$ \\
3 & $11.85 \pm 0.42$ & $>100$ \\
4 & $8.97 \pm 0.25$ & $>100$ \\
5 & $8.32 \pm 0.19$ & $>100$ \\
6 & $15.61 \pm 0.32$ & $>100$ \\
7 & $13.18 \pm 0.27$ & $>100$ \\
8 & $12.40 \pm 0.32$ & $>100$ \\
9 & $15.39 \pm 0.26$ & $>100$ \\
10 & $13.56 \pm 0.23$ & $>100$ \\
11 & $7.41 \pm 0.19$ & $>100$ \\
12 & $6.68 \pm 0.21$ & $14.92 \pm 0.57$ \\
Galantha- & $0.14 \pm 0.39$ & \\
mine & $0.43 \pm 0.03$ & \\
\hline
\end{tabular}

${ }^{\text {a }}$ Data are means \pm standard error of the mean of triplicate independent experiments.

Generally, all of the synthesized compounds possessed moderate acetylcholinesterase inhibitory activity with different ratios. Regarding compounds bearing chloride substituent, pyrazole derivatives have better AChE inhibitory activity than 1,2,4-triazole analogues. On the contrary, among the compounds bearing methoxy substituent, 1,2,4-triazole derivatives displayed better AChE inhibitory activity than their pyrazole analogues. Besides, activity evaluation of the 1,2,4-triazole derivatives within themselves indicated that replacement of chloride substituent with methoxy group remarkably increased the AChE inhibitory activity.

Bir grup fenilasetamit türevi bileşiklerin sentezi ve kolinesteraz inhibitör aktivite çalışmaları

\section{ÖZET}

Pirazol veya 1,2,4-triazol taşıyan bir grup $N$-fenilasetamit türevi sentezlenmiş ve kolinesteraz inhibitör aktiviteleri test edilmiştir. Asetilkolinesteraz ve bütirilkolinesteraz inhibitör aktiviteleri Ellman’n spektroskobik metoduna
Among the pyrazole derivatives, the most active compounds are compound 3 and 4 with $\mathrm{IC}_{50}$ values $8.97 \mu \mathrm{M}$ and $8.32 \mu \mathrm{M}$, respectively while in 1,2,4-triazole derivatives, compounds $\mathbf{1 0}$, 11, 12 displayed the most inhibition against $\mathrm{AChE}$ with $\mathrm{IC}_{50}$ values $7.41 \mu \mathrm{M}, 6.68 \mu \mathrm{M}$ and $8.14 \mu \mathrm{M}$, respectively. Compound 11, namely 2-(1H-1,2,4-triazole-1yl)- $N$-(3-methoxyphenyl) acetamide, was the most active compound in the series.

According to BuChE inhibitory activity results, none of the compounds displayed any inhibitory activity. Thus, we can easily point out that all of the title compounds are selective AChE inhibitors.

\section{Docking Studies}

In this study, molecular docking study was performed using GOLD 5.2.1 to predict the interaction mode of compound 11 for AChE. The X-ray crystal structure of the TcAChE in complex with donepezil (PDB code 1EVE) was selected to build the starting model of AChE. Compound 11 was chosen for molecular modeling as the most active compound in the series (Table 1).

As shown in Figure 1, compound $\mathbf{1 1}$ has two major binding interactions with TcAChE. 1,2,4-triazole ring can interact with Phe330 residue and $N$-phenyl ring can interact with Tyr334 residue through $\pi-\pi$ interactions. Phe330 is located in the hydrophobic pocket near the catalytic site of AChE (CAS) and it is known that several AChE inhibitors including tacrine have binding interactions with Phe330 (30). On the other hand, Tyr334 is located in the peripheral site (PAS) of the enzyme and it can be proposed that compound 11 can interact with the PAS site of AChE. We have already mentioned that the narrow conformation of the AChE enzyme gorge leads small molecules like tacrine and donepezil to fit into the active site easily so it can be speculated that as our compounds are small molecules, they possessed AChE inhibitory activity. On the other hand, we can also speculate that our compounds didn't display any BuChE inhibitory activity due to the larger active site gorge of $\mathrm{BuChE}$ in respect to $\operatorname{AChE}(18,30)$.

göre test edilmiştir. Elde edilen sonuçlar, tüm bileşiklerin orta derecede ve seçici asetilkolinesteraz inhibitör aktivite gösterdiğini ortaya koymuştur. Serideki en aktif bileşik $6.68 \mu \mathrm{M}^{\prime} l \mathrm{lk} \mathrm{IC}_{50}$ değeriyle 2-(1H-1,2,4-triazol-1-il)- $\mathrm{N}$-(3metoksifenil)asetamit olup bu bileşiğe doking çalışmaları da yapılmıştır.

Anahtar kelimeler: Alzheimer hastalığı, pirazol, 1,2,4-triazol, asetamit, kolinesteraz inhibitör aktivite 


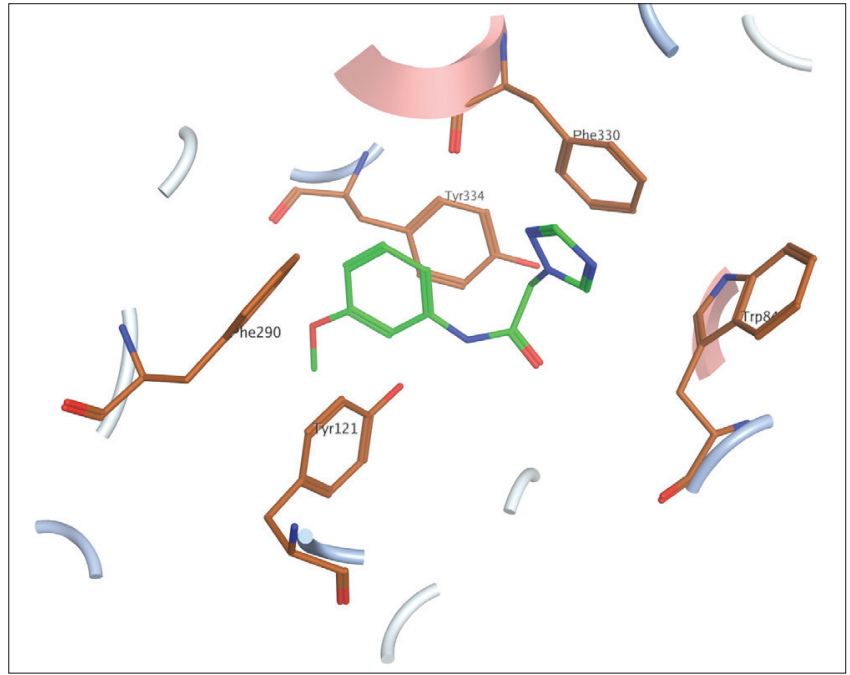

Figure 1. Binding mode of compound 11 inside TcAChE. Compound $\mathbf{1 1}$ is represented as green stick; the most involved residues are named and represented as brown sticks for the TcAChE.

In conclusion, the preliminary activity screening results have demonstrated that $N$-phenylacetamide template bearing pyrazole and 1,2,4-triazole rings have selective acetylcholinesterase inhibitory activity and preliminary molecular modeling studies proposed a binding interaction between the most active compound and the PAS region of AChE. These findings can be assumed as the beginning for further studies to design more effective acetylcholinesterase inhibitors binding both PAS and CAS sites of the AChE enzyme.

\section{ACKNOWLEDGEMENTS}

This study was supported by research grants from Ege University (Project Number: 11/Ecz/028). The authors would like to thank Pharmaceutical Sciences Research Centre (FABAL) at Ege University Faculty of Pharmacy for spectral analyses.

\section{REFERENCES}

1. Holzgrabe U, Kapková P, Alptüzün V, Scheiber J, Kugelmann E. Targeting acetylcholinesterase to treat neurodegeneration. Expert Opin Ther Targets 2007;11: 16179.

2. Abramov AY, Canvari L, Duchen MRJ. Changes in intracellular calcium and glutathione in astrocytes as the primary mechanism of amyloid neurotoxicity. J Neurosci 2003; 15: 5088-95.

3. Barreio EJ, Camara CA, Verli H, Brazil-Mas L, Castro NG, Cintra WM, Arcava Y, Rodrigues CR, Fraga AM, Design, Synthesis, and Pharmacological Profile of Novel Fused Pyrazolo[4,3- $d]$ pyridine and Pyrazolo[3,4- $b]$
$[1,8]$ naphthyridine Isosteres: A New Class of Potent and Selective Acetylcholinesterase Inhibitors. J Med Chem 2003; 46: 1144-52.

4. Wang H, Zhang D, Wang F, Wu Y, Song H. Synthesis and Anticholinesterase Activity of (-)-Physostigmine Analogues with Modifications at C3a and C5. Chem Res Chin Univ 2013; 29(5): 888-93.

5. Shi A, Huang L, Lu C, He F, Li X. Synthesis, biological evaluation and molecular modeling of novel triazolecontaining berberine derivatives as acetylcholinesterase and b-amyloid aggregation inhibitors. Bioorgan Med Chem 2011; 19: 2298-2305.

6. Genest D, Rochais C, Lecoutey C, Santos JSO, Ballandonne C, Butt-Gueulle S, Legay R, Since M, Dallemagne P. Design, synthesis and biological evaluation of novel indano- and thiaindano-pyrazoles with potential interest for Alzheimer's disease. Med Chem Commun 2013; 4: 925-31.

7. Razavi SF, Khoobi M, Nadri H, Sakhteman A, Moradi A, Emami S, Foroumadi A, Shafiee A. Synthesis and evaluation of 4-substituted coumarins as novel acetylcholinesterase inhibitors. Eur J Med Chem 2013; 64: 252-59.

8. Soyer Z, Parlar S, Alptuzun V. Synthesis and acetylcholinesterase (AChE) inhibitory activity of some $\mathrm{N}$-substituted-5-chloro-2(3H)-benzoxazolone derivatives. Marmara Pharm J 2013; 17: 15-20.

9. Kumar H, Saini D, Jain S, Jain N. Pyrazole scaffold: A remarkable tool in the development of anticancer agents. Eur J Med Chem 2013; 70: 248-58.

10. Kumar A, Jain S, Parle M. Synthesis, biological evaluation and molecular modeling studies of 3-aryl-1- phenyl- $1 H$ pyrazole derivatives as novel acetylcholinesterase inhibitors. Der Pharmacia Lettre, 2013; 5(4): 286-95.

11. Yurttaş L, Kaplancıklı ZA, and Özkay Y. Design, synthesis and evaluation of new thiazole-piperazines as acetylcholinesterase inhibitors J Enzm Inhib Med Ch 2013; 28(5): 1040-1047.

12. Khan KM; Siddiqui S, Saleem M, Taha M, Saad SM, Perveen S, Choudhary MI. Synthesis of triazole Schiff bases: Novel inhibitors of nucleotide pyrophosphatase/ phosphodiesterase-1. Bioorg Med Chem 2014;22: 6509-14.

13. Khan I, Ibrar A, Zaib S, Ahmad S, Furtmann N, Hameed S, Simpson J, Bajorath J, Iqbal J. Active compounds from a diverse library of triazolothiadiazole and triazolothiadiazine scaffolds: Synthesis, crystal structure, determination, cytotoxicity, cholinesterase inhibitory activity, and binding mode analysis. Bioorg Med Chem 2014;22: 6163-73.

14. Mohsen UA, Kocyigit-Kaymakcioglu B, Celen AO, KaplancikliZA.Some Urea and Thiourea Derivatives Bearing 1,2,4-Triazole Ring and Their Anti-Acetylcholinesterase Activities. MÜSBED 2014;4: 85-9.

15. Tarikoğulları AH, Kılıç FS, Erol K, Pabuçcuoğlu V. Synthesis and anticonvulsant activity of some alkanamide derivatives. Arzneimittel-Forsch 2010; 60: 593-8.

16. Li M, Zhao BX. Progress of the synthesis of condensed pyrazole derivatives (from 2010 to mid-2013). Eur J Med Chem 2014; 85: 311-40.

17. Sussman JL, Harel M, Frolow F, Oefner C, Goldman A, Toker L, Silman I. Atomic structure of acetylcholinesterase from Torpedo californica: a prototypic acetylcholine- 
binding protein. Science 1981; 253: 872-9.

18. Alpan AS, Parlar S, Carlino L, Tarikogullari AH, Alptüzün V,Güneş HS. Synthesis, biological activity and molecular modeling studies on $1 \mathrm{H}$-benzimidazole derivatives as acetylcholinesterase inhibitors. Bioorg Med Chem 2013;21: 4928-37.

19. Johnson JL, Cusack B, Davies MP, Fauq A, Rosenberry TL. Unmasking Tandem Site Interaction in Human Acetylcholinesterase. Substrate Activation with a Cationic Acetanilide Substrate. Biochemistry US 2003;42: 5438-52.

20. Gangi FED. Synthesis of some betadialkylaminopropioanilides. J Am Chem Soc 1955; XLIV: 135-7.

21. Zalaru C, Dumitrascu F, Draghici C, Cristea E, Tarcomnicu I. Pharmacologically active 2-(1H-pyrazol-1-yl)acetamides. Arkivoc 2009; 2: 308-14.

22. Ellman GL, Courtney KD, Andres V Jr, Feather-Stone RM. A new and rapid colorimetric determination of acetylcholinesterase activity. Biochem Pharmacol 1961; 7: 88-95.

23. Kapkova P, Stiefl N, Sürig U, Engels B, Baumann K, Holzgrabe U. Synthesis, biological activity, and docking studies of new acetylcholinesterase inhibitors of the bispyridinium type. Arch Pharm Chem 2003; 336: 523-40.
24. Molecular Operating Environment (MOE 2011.10) Chemical Computing Group Inc., 1010 Sherbrooke Street West, Suite 91, Monsteal H3A 2R7, Canada.

25. Jones G, Willett P, Glen RC, Leach AR, Taylor R. Development and validation of a genetic algorithm for flexible docking. J Mol Biol 1997;267: 727-48.

26. Banerjee S, Ganguly S, Sen KK, Choowongkomon K, Seetaha S. Synthesis, evaluation and binding mode analysis of some novel triazole derivatives as antimicrobials. JAPER 2013; 3: 494511.

27. Stankovsky S, Jedlovska E, Spirkova K. Synthesis of some triazolyl acetanilides. Collect Czech Chem Commun 1993;58: 2211-4.

28. Hesse M, Meier H, Zeeh B. Spectroscopic Methods in Organic Chemistry. Stuttgart, New York. 1997.

29. Nakanishi K, Solomon PH. Infrared Absorption Spectroscopy. Emerson Adams Press Inc, San Francisco. 1977.

30. Galdeano C, Viayna E, Arroyo P, Bidon-Chanal, Blas JR, Munoz-Torrero D, Luque FJ. Structural Determinants of the Multifunctional Profile of Dual Binding Site Acetylcholinesterase Inhibitors as Anti-Alzheimer Agents. Curr Pharm Des 2010;16: 2818-36. 